\title{
The Ancient Hebrew Inscription Discovered at the Pool of Siloam in Jerusalem
}

\section{A. H. Sayce}

To cite this article: A. H. Sayce (1881) The Ancient Hebrew Inscription Discovered the Pool of Siloam in Jerusalem, Palestine Exploration Quarterly, 13:3, 141-157, DOI: 10.1179/ peq.1881.13.3.141

To link to this article: http://dx.doi.org/10.1179/peq.1881.13.3.141

册 Published online: 20 Nov 2013.

Submit your article to this journal $₫$

Џll Article views: 8

Q View related articles $\square$ 
Copy of the Inscription of Siloam.

•.

至

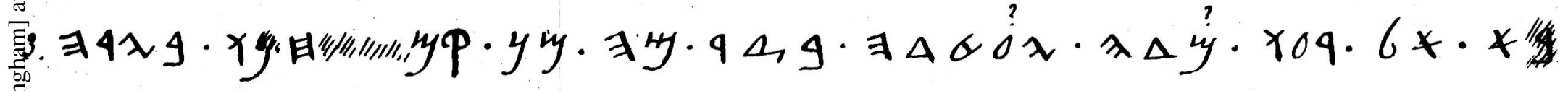

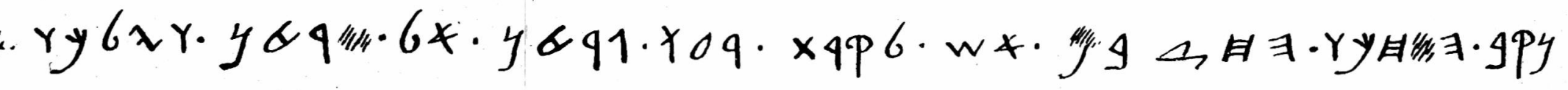

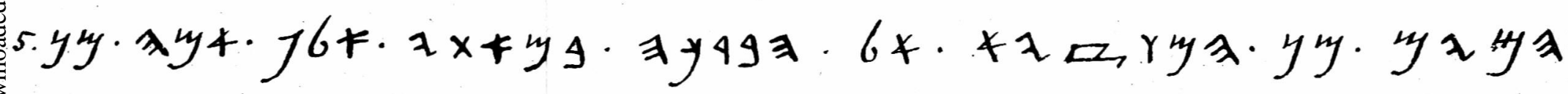

6.

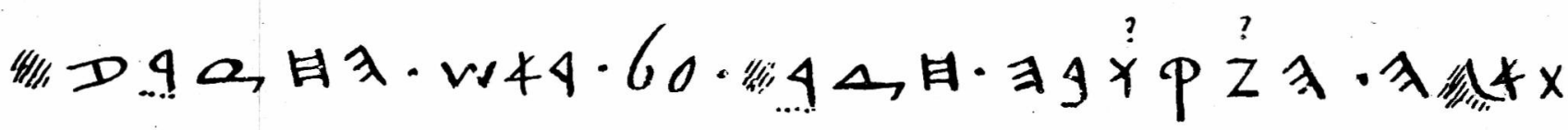




\title{
THE ANCIENT HEBREW INSCRIPTION DISCOVERED
} AT THE POOL OF SILOAM IN JERUSALEM.

I.

\author{
By the Rov. A. H. SAYce.
}

Is June, 1880 , an important discovery was accidentally made at the Pool of Siloam on the southern side of Jerusalem. One of the pupils of Mr. Schick, a Gernan architect loug settled in Jerusalem, was playing here with some other lads, and while wading up a chaunel cut in the rock which leads into the pool slipped and fell finto the water. On rising to the surface he noticed what looked like letters on the rocky-wall of the channel. Ho told Mr. Schick of what he had seen, and the latter accordingly visited the spot ns soon as possible.

The channel in question is an ancient conduit which conveys the water of the Virgin's Pool (Birlet Sitti Maryam) on the enstern side of the city to the so-called Pool of Silonm. It is cut through the rock, and so forms $\Omega$ subterranean passage through the southern spur of the hill on which the Mosque of Omar stands. The Pool of Siloam lies on the eastern side of the ancient valley of Tyropoeon, at a considerable depth below the summit of the Temple hill. The passage connecting the two pools has been explored by Robinson, Tobler, Colonel Warren, and others. Ac.ording to Colonel Warren, its length is 1,708 feet ( 569 f yards),* though the listance from the one pool to the other in a direct line is only 368 yards. The passage, however, is not straight ; it winds considerably, and there are several culs $d e s a c$ in its course, from which we may infer that the engineering knowledge of its excavators was not sufficient to prevent them from missing their way. As we shall see, the newly found inscription shows that the passage was excavated from both ends, the workmen meeting in the middle, like the excavators of the Mont Cenis Tunnel. The height varies greatly, but the width is pretty uniform. I attempted ta walk up it from its lower or Siloam end, along with my companion Mr. J. Slater, but after proceeding some distance the roof became so low that, in order. to proceed it would have been necessary to crawl on all fours through a thick deposit of black mud, and this, as we had no suitable dresses, we declined to do. However, I made my way sufficiently far to acquaint myself fully with the mode in which the channel had been constructed.

- Robinson makes it about 686 yards. 
The roof is flat rather than arched, but the floor is hollowed into a groove, to admit the passage of the water, so that the generil form of the conduit is that of an inverted sugar-loaf, thus $U$. In some places I observed water trickling through fissures in the rocky wall of the channel, and here and there deposits of black mud had found their way into it through similar breaks in the rock. The whole bed of the channel, however, was covered with a layer of soft nuud from half-a-foot to a foot and a half in depth. The walls of the conduit, like the roof, are for the most part left rough ; but now and then I cime across small portions which had apparently been smoothed, as well as hollows or niches in the face of thew all.

The inscription discovered by Mr. Sshick is in a niche of this kind, at the lower end of the conduit, and about 19 feet from the place where it opens out into the Pool of Siloam. The conduit is here from 20 inches to 2 feet in breadth, and the niche in which it is engraved is 27 inches long by 26 wide, the niche itself being cut in the rock-wall of the channel in the form of a square tablet, to a depth of an inch and a-half, and made smooth to receive the inscription. It is on the right-hand side of the conduit as one enters it from the Pool, and consequently on the eastern wall of the tunnel. The upper part of the tablet or niche has been left plain, though a graffito has been scratched across it, which is probably of late date. The lower part alone is occupied with the inscription, which consists of six lines, and an ornamental finish has been added below the middle of the last line in the shape of two triangles, which rest upon their apices, with a similarly inverted angle between them. On the left side of the tablet the rock is unfortunately fractured, resulting in the loss of several characters in the first four lines. According to the Rev. W. T. Pilter's measurements, the upright lines of the characters in the first line are about half-an-inch in length, those in the second line about $\frac{3}{5}$ ths of an inch, while in the remaining lines they average ${ }_{n}^{\mathrm{n}}$ ths of an inch. In the wall immediately opposite the tablet a triangular niche has been cut Mr. Schick suggests that it was intended to hold the lamp of the workman employed in engraving the inscription. At the time the inscription was found, the greater part of it was below the level of the water which flows from the Pool of the Virgin into the Pool of Siloam. This will explain why it was not seen by former explorers of the conduit. The passage of the water has filled the characters with a deposit of lime which makes it difficult to read them, and in the last line the letters are almost entirely smoothed away by the friction of the water. Before the inscription could be copied it was first necessary that the level of the water should be lowered. This was done at the expense of the Palestine Exploration Fund, the Committee, immediately after hearing (in August) of the discovery, having authorized Dr. Chaplin to draw upon them for the money necessary for the work.* At the same time Mr. Schick was asked to take a better copy of the inscription than the one which had been sent to * According to Dr. Kauizsch (Allgemeine Zeitung for April 29th) the
German Palestine Exploration Society also sent money for the same purpose, 
England. This he did in January, but as he was unacquainted with Phonician epigraphy his succes was not great, and the copy could not be read. A second copy, which arrived in England on the lst of March, and was published in the last Quarterly Statement of the Fund (April 1881), proved equally unintelligible.

Meanwhile, I had succeoded in taking what I believe to be the most perfect copy of the iuscription that can well be obtained. An accident I met with in Cyprus brought me unexpectedly to Jerusalem at the beginning of last February, and one of my first occupations there was to call on Mr. Schick, and enquire about his discovery. He showed me his copy of the inscription-the same facsimile as that forwarded to London in January - and explained to me the difficulties he had laboured under in attempting to make it. I saw at once that it contained characters of the early Phoenician alphabet, and accordingly started as soon as I could for the couduit where it was found, in compuny with another gentleman, Mr. J. Slater.

Mr. Schick had not exaggerated the difficulties which stood in the way of making an rocurate transcript of the inscription. The last line of it was only just above the level of the water, which, though reduced very considerably below its former lovel, was still from 4 to 6 inches deep, and flowed with a steady and rapid current. In this it was necessary to sit in order to copy the concluding lines of the inscription, and the cramped position necessitated by the narrownoss of the space was very fatiguing to the limbs after an hour or two's work. As there was no light so far up the conduit, the characters could only be seen by the din light of a candle. This Mr. Slater was good onough to hold for me,-conduct the more heroic in that he suffered severely from the mosquitoes with which the conduit swarmed. As the letters were filled with lime, they could be distinguished only by tracing the white marks of the lime upon the darker surface of the smooth rock. Besides the letters, however, every accidental scratch and flaw in the stone wis equally filled with lime, thus making it impossible for any one unacquainted with Phcenicinu pelæography to take a correct facsimile of the inscription.

The copy of the inscription here published is the result of three separate visits to the spot where it was found. It was only by repeated observation that the actual forms of some of the characters became clear to me, and it will be seen that there are several which still remain doubtful. Since my return to Englund, I have received another copy of the inscription, made independently of my own, by the Rev. W. T. Pilter, which the author has been kind enough to send me. The commentary will show of what service a comparison of this with my ow'n copy has been to me. I understand from Mr. Pilter, that Dr. Guthe, the head of

but this seems not to be quite correct. Dr. Kautzsch has been in such a hurry to vindicate the German Paleotine $\Delta$ ssociation, that he supposes Mr. Schick's copy of the inscription, published in the Quarterly Statement, to be mine. 


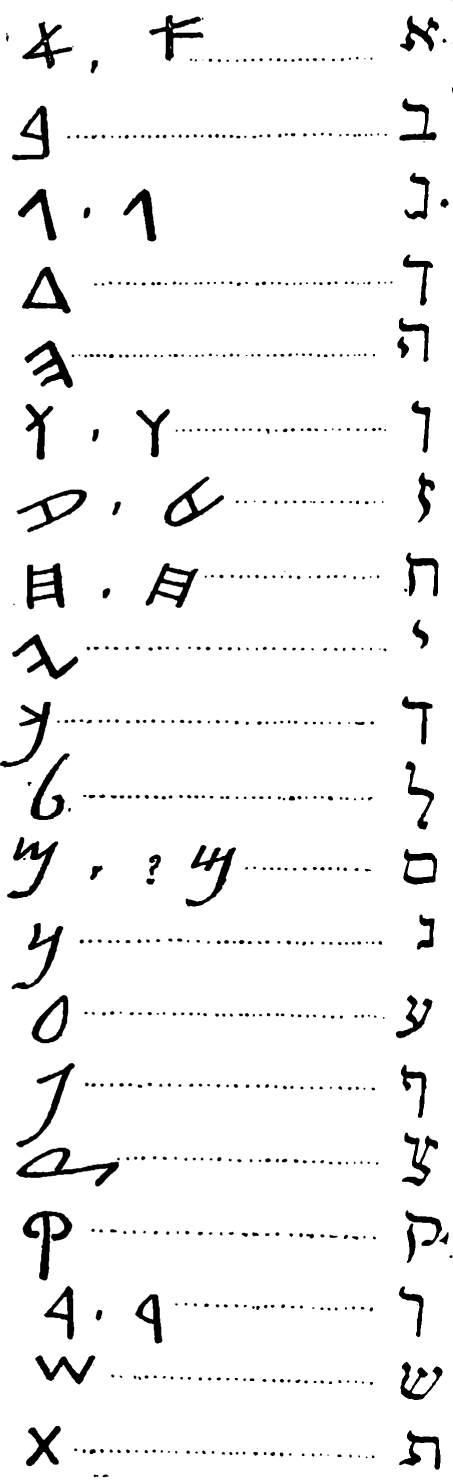

the German Palestine Exploration Society, who has lately arrived at Jerusalem, is having the whole conduit cleared out, in -order to discover whether a second inscription is visible at the ether end.

The inscription is the oldest Hebrew record of the kind yet discovered. The word שN which occurs thrice in it made me at one time believe that it was a Phœnician monument, being the Phœnician relative pronoun. M. Halevy,* however, pointed out that UN must be only a defective spelling of the Hebrew W'N, - which, by the way, throws light on the derivation of the Phœenician relative pronoun,-and since the language of the inscription is in all other respects that of Biblical Hebrew, including an example of waw conversive, that characteristic peculiarity of Hebrew idiom, no doubt can now remain as to its true nature. It is an early contemporaneous specimen of the language of the Old Testament. written in that ancient form of the Phœnician alphabet already known to us from the Moabite Stone and a few legends on seals.

The form of the alphabet, however, belongs to an even older period than that of the Moabite Stone. While the words are divided from one another by single points, and the opening sentences by double points, as on the Moabite Stone, and while, too, the majority of the letters have exactly the same

* See the Athencum, May 14th, 1881. 
forms as those represented on the monument of King Mesha, three of the latter, wav, zayin, and tacudhe, are more anchaic in shape than the corresponding letters in the Moabite inscription. The rayin was first identified by Dr. Neubauer, and, like the toadhe, presents us with a form from which the forms found on the Moabite Stone and in later inscriptions are derived by dropping the loop, and in the case of the teadhe by yet further modifications ( 6, Moabite $\& ; \infty$, Mabite $F$ ). The form of wavo, though older than that of the Moabite alphabet, nevertheles resembles that of the early Hebrew seals, as well as of the Nimroud lion weights (8th century B.c.) The koph, again, resembles that of the ancient Hebrew legends rather than that of the Moabite and early Phonician texts. So, also, does the beth with the long horizontal line at its base. On the other hand, the daleth, caph, lamed and tau are those of the Moabite Stone, not of the Hebrew seals, but the long rounded "tail" of the caph, mem, nun and pe remind us more of the Hebrew than of the Moabite inscriptions. The kheth, too, has three horizontal bars instead of only two as on the Monbite Stone. On the whole, the Siloam inscription presents us with a form of the Phenician alphabet considerably older than any previously known, and more closely resembling that of the Moabite Stone than any other, although the early form of the waw found in it, which was lost in the Moabite alphabet, long survived in the more conservative alphabet of the Jews An interesting specimen of the alphabet of the ancient Hebrew seals will be found in the last number of the Journal of the German Oriental Society (xxxiv, 4), bearing the inscription "Belonging to Abu-Yahu (Obadiah) servant of the king." As it was bronght from the neighbourhood of Diarbekr, it .may have formed part of the booty carried away from Judra by Sargon or Seunacherib. I may add that the form of the eayin in the Siloam inscription supports De Rouge's attempt to derive the Phonician alphabet from the hieratic form of the Egyptian alpliabet during the period of the Hyksos ; though as much cannot be said of the wav und tradhe.

Palæographically, therefore, the age of the newly-found inscription is greater than that of the Monbite Stone. Now a glance at the map will show that the Moabites must have obtained their alphabet, not directly from Phœnicia, but through either Judah or the southern half of the Kingdom of Ismel, more probnbly the latter. As it is difficult to suppose that a more archaic form of the alphabet was in use at Jerusalem than at Samaria during the same period, it would follow that the alphabet of the Siloam inscription, and therefore the inscription itself, would be more ancient than the inscription of Mesha, that is to say, than the ninth century B.c. We may accordingly ausign it to the age of Solomon, when great public works were being constructed at Jerusalem, more especially in the neighbourhood of the Tyropocon valley. At all events, the historical records of the Old Testament do not warrant our assuming that further works of the kind were constructed at Jerusalem until we come to the time of Hezekiah, who "stopped the upper watercourse of Gihon, and 
brought it straight down to the west side of the city of David." (2 Chron. 32, 30.) This could not be the conduit of Silonm, as the city of David lay on the western side of the Tyropxeon. Isaiah refers to this work of Hezekiah when he tells the rulers of Jorusalen that they had "gathered together the waters of the lower pool" (ברכר) and had "made also a ditch (or reservoir) between the two walls for the waters of the old pool" (ברכד.) (Isaiah xxii, 9, 11 ; see vii, 3.) The pulıographical evidence of the inscription, however, is wholly agrinst our aswigning it to so late a period as the time of Hezekiah ; and this is the unly evideuce that is at present procurable.

The seal brought from the neighbuurhoor of 1)iarbokr affords further evidence in this direction. The king, whose servant the owner calls himself, would be the king of either Judah (or Simuria) or of Angria, and we are therefore justified in dating it as least us early as the seventh century B.c. This brings us near the period of Hezekiah. But, as we have seen, the alphabet of Siloum is older than that of the seal.* The construction of a tunnel like that which connects the Pools of the Virgin and Siloam implies both skill and wealth, such in would low more consistent with the epoch of Solomon than with any othor in tho history of the kingdom of Judah. So far as we know, Phornicimn workmen were not afterwards employed by the kings of Juduh, and it may be doubted whether any native Jew possessed the engineoring ability dinplayod, as the inscription seems to show, in the excavation of the conduit. Dr. Neubauer has pointed out to me that the work must have been begun at both ends simultaneously, the workmen finally meeting in the middle, like the excavators of the Mont Cenis tumnel. 'This will nccount for the culs de sac met with in the passage. It was no wonder that one of the workmen, perhaps the chief engineer himself, recorded the succersful completion of the undertaking in writing. The ouly difliculty is to explain why the upper half of the tablet in which the inscription is engrnved is left smooth, the lower half alone being occupied with the inscription. I can only suggest that a historical record of the work was intended to be inscribed in the unengraved portion of the tablet, but that for some reanon or other the intention was never carried out, while the existing inscription itself, being merely the composition of a private individua, was eugraved in a plase where it would be permanently concealed by the water.

The size and clearness of the letters show that writing was no very unusual accomplishment in Jerusalem at the perioxl when the inscription was engraved. At the same time, some of the letters have duplicate forms, which equally seem to show that it wns in a somewhat unfixed state. Aleph has two forns, one of which is identical with the form found on the Hebrew coins, while the other is the form of the Moabite

* Another seal of Hebrew origin, with the legend figure which has been compared with "the Golden Calf" of Dan, found on the banks of the Euphrates, cannnt be cited as ovidence, as it may be of the period
of the Exile. 
and Phœnician inscriptions : zayin, also, has troo forms, the loop appearing ou the left hand side in one of them, on the right hand aide in the other; so, too, perhaps, have wave and mem, though I do not fool absolutely certain about the form $\boldsymbol{\gamma}$ and 5 . I can throw no light on the curious ornament which serves as a finis to the inscription.

Historically, the inscription gives us no information beyond the nere record of the cutting of the conduit. Topographically, also, our gains from it are small. We learn that the Pool of siloam was known as the B'rechah, or "Pool," and if my reading is right the Btrah, or "Castle," mentioned in Neh. ii, 8, and vii, 2 , ulready existed on the Temple area. Jusephus calls the latter the Bdpes (Antig. 15, 11, 4), and it atood not very fur from the modern gate of St. Stephen and the Virgin's Pool. In the Roman period it was known as the Tower of Antonia. M. Halovy, however, has very ingeniously suggested that the mention of the 'eleph ammah or "thousand cubits" in the tifth line nay throw light upon two passages of the Old Testament, Josh. xviii, 28, und Zech. ix, 7. In the first the rendering of the A. V. should be corrected into "And Teeln', the Eleph and the Jebusi, that is Jerusalem." which would mesu that Jerusalem consisted of the three quartors of Tsela', Eleph, and Jebusi, the latter being the Jebusite stronghold, captured by David, to the weet of the Teuple hill. In the second pasage a slight alteration of the punctuation

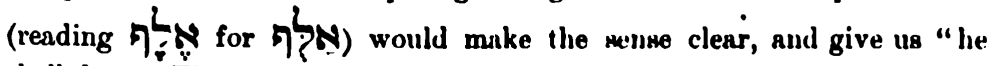
shall be as Eleph in Judah, even Ekron as Jebusi." If M. Halovy is right, the "thousand" cubits of the concluit gave its name to the rocky height, through which it was cut, so that the southern part of the Temple hill, facing Jebusi or the "City of Duvid" was known as Eleph or "The Eleph."*

Metrologically the inscription seoms to fix the length of the Hebrew cubit, or 'ammah, the tunnel which, sccording to Colonel Warren, is 1,708 feet in length, heing said to be a thousand cubits long. In this case the cubic would equal $2(1)$ inches. But it must be remembered that a thousand is a round number, and should not be pressed ton closely.

For philology and epigruphy the value of the inscription is very grent. It not only gives us the Phavician alphnbet in a more archaic form than any previously known, but it brings before us the Hebrew language as it was actually spoken in the age of the kinga. The Hebrew scholar cannot but be struck l,y what may be termed the biblical characler of the language. The very idioms to which he has been accustomed in the Old Testament reappear in this ancient record. At the anme time it offers more than one peculiarity. Unless my reading is wrong, we have in the second line TISN whey instend of תinN. The same peculiarity, however, is presented by the first word of the last line, which, although in the construct state, ends with he instead of tau. It would therefore appear that the engraver carried the tendency to reduce a final th to $h$ even

- Sec the .1thenawm, Mas 14th, 1881. 
further than the classical Hebrew of the Bible. He has also written $N$ to express the vowel $a$ in two instances which cannot be paralleled in Biblical Hebrew, במאתי in line 5. The same scriptio plena shows itself in מרציא (line 5), though on the other hand איש is throughout written defectively for The spelling of the latter word is interesting as its suggests the etymology of the Phonician relative pronoun wא. Other peculiarities of the inscription will be the use of the Hithpael of חכה in the peculiar sense of "eagerly working at," and the employment of a word unknown to Biblical Hebrew, which terminates with הדר (line 3).*

But the chief interest of the inscription lies in the indication it affords of the extent to which writing was known and practised among the Jews in the early age to which it belongs. It thus confirms the testimony of those Old Testament scriptures which claim to have been written during the oldest period of the Jewish State. And its evidence will have to be considered in future enquiries as to the epoch at which the Phœnician alphabet was first introduced among the Hebrew people. Above all, its discovery leads us to hope that other Hebrew inscriptions of an ancient date are yet to be found in Jerusalem itself. "Underground Jerusalem" has been as yet but little explored, and if we may find a record of the kind in a spot which is easily accessible, and has been not unfrequently visited, what discoveries may we not expect to make hereafter when the Temple area can be thoroughly investigated, and the subterranean watercourses of the capital of the Jewish monarchy laid open to view.

Transliteration of the Inscription in the Hebrew Square Character.

ו הן . (ד) עקבה: וזדה . היה . (ע ?)בר . המקבה: בעוד (החצ)

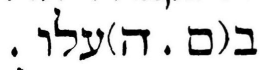

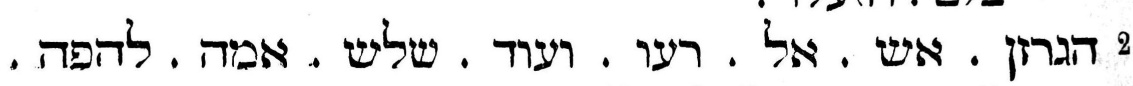

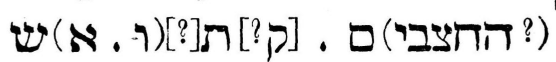

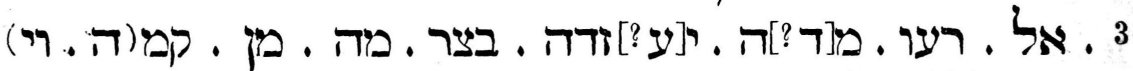
דבו . בירה באים

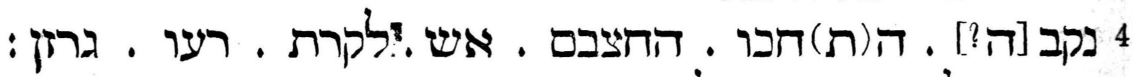

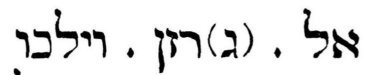

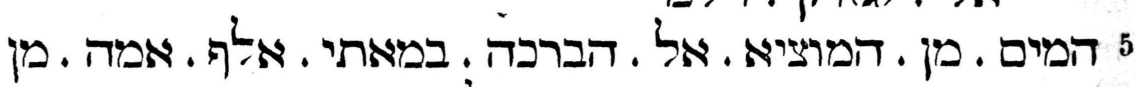

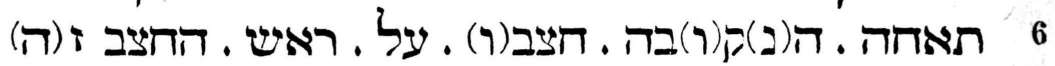

* M. Derembourg has suggested that the מוציא of line 5 is to be identified with the מוצא of the Talmud. See Neubauer, "La Géographie du Talmud," pp. 152, 153. The Talmudical Motsa, howerer, is described as being near Jerusalem, not as forming part of the city, and as also bearing the Greek name of Kolonia (Athencum, May 14th, 1881). 


\section{Translation.}

Behold the excavation! Now this is the further side (or the history) of the tunnel. While the excavators were lifting up the pick, each towards his neighbour, and while there were yet three cubits to the mouth (of the tunnel) the excavators were hewing. Each came to his neighbour at a measure's length (?) . . . . in the rock on high ; and they worked eagerly at (the) castle they had excavated (?); the excavators worked eagerly each to meet the other, pick to pick. And the waters flowed from their outlet to the Pool for a distance of a thousand cubits, from the lower part (?) of the tunnel (which) they excavated at the head of the excavation here."

\section{Commentary.}

Line 1. The sense obviously requires room. I had conjectured that this word ought to be read when I received Mr. Pilter's copy. In this he has two characters which are clearly followed by a point. His copy, however, shows no trace of a $\rightarrow$ before the next word, though without it the grammar would be awkward, and I have therefore ventured to supply the missing letter. I was unable myself to make out the first letters of this line.

I read נקבה ; Mr. Pilter's copy has in which case we had better translate "tunnel" rather than "excavation." The verb means "to bore" and is therefore well fitted to denote the construction of a tunnel. In Assyrian it is used of the construction of watercourses. For a similar signification of מקבה in Hebrew see Is. li, 1. should not be rendered "hammer" as in the A. V. (1 Kings 6, 7; Is. xliv, 12 ; Jer. $x, 4$ ), but "boring-tool" as is plain from this inscription. The name of Macchabæus, therefore, even supposing it were written מבבי מבי מקב as it is, would not mean "the hammer."

The character which precedes בר is unfortunately doubtful. My first copy gave $p$, but קבר is used in Hebrew only of graves, not of excavations generally. In my third copy I made the character $ה$; הברר would give but poor sense, and the grammar would be awkward. Mr. Pilter's copy has $\mathbf{\aleph}$, like the facsimile published by the Palestine Exploration Fund in their last Quarterly Statement; this is obviously impossible. Dr. Neubauer has suggested דבר, which would give the meaning required, and agree with the Biblical style. I wish I could adopt it without misgiving, but my copies agree in delineating a loop rather than an angle, and I am therefore inclined to read עבר, supposing the sense to be that the lower end of the tunnel where the inscription is engraved had been the further side of the excavation, which was begun first at the other end.

After בערד comes a fracture of the rock, and it is possible that more, letters ought to be supplied than those with which I have conjec. 
turally filled up the lacuna. After $\supseteq$ there is not room for more than two letters, and דתבמש is spelt defectively without 7 in line 4.

I believe my restoration of דתעל is certain. The last letter is clear; the preceding one, though much obliterated, can only be a $\zeta$, and before that comes a small triangular cake of lime which is two snuall to represent a daleth, and can therefore only be $y$. The sense given by העצר is just that which is wanted.

Line 2. ברז must signify "a pick" here, not an "axe." This will be also its meaning in 1 Kings vi, 7 .

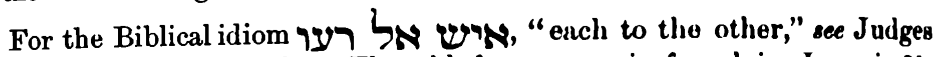
vi, 29; 1 Sam. x, 11, \&c. The old form רער is found in Jer. vi, 21. M. Halévy was the first to notice that exN is a defoctive spelling of שרי It is similar to the defective spelling of פבת. The spelling throws light on the etymology of the Phonician relative pronoun wN, which will have originally meant "man," and mecordingly had no connection with the Hebrew relative רשN, which originally signified "place." Over the first letter of רער is a mark, which does not seem to be a mere accidental scratch, but which I cannot expluin.

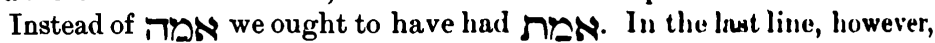
the engraver has made the final letter of a feminine noun in the construct state $\pi$ instead of $\Omega$, and it would therefore seem that the tendency of Hebrew to change final thinto $h$ had in his case gone considerably further than in the classical language of the Old Testnment. If no, the inscription will afford us an interesting specimen of the local dinlect of Jirusulem.

We may notice that the article is expressed in writing in 7 ? in contradistinction to בצר in the following line.

After the break in this line, caused by the fructure of the rock, we have, according to my copy, the lower part of a letter which is either a $\square$, a , or a 7 ; then a point; then the remains of a charncter which may be either $\boldsymbol{N}$ or $\boldsymbol{p}$, and then space for two letters, one of which I have copied very doubtfully as $\Omega$. The other copies give no help. AN the sense requires the third pers. pl. of a verb, I supply the final q, and read conjecturally קצו "they hewed off." See Hab. ii, 10. The seuse shows that we have to supply $N$ before the final $\mathbb{W}$.

Line 3. Here my copies would make the first character 2. กา, however, and the word which follows it, are extremely puzzling. The three last letters of the second word are certnin, and are anong the clearest characters in the whole inscription. Yet the only Hebrew root with which they can be brought into connection is 7nr, "to seethe." It

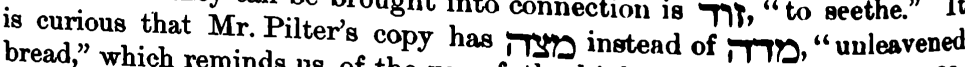
bread," which reminds us of the nse of the hiphil of Thi in Gen. $\times \times v, 29$, in the sense of preparing food. But neither the context nor the grammar agree with this reading, whereas my 7 Tा suits the passage well. Of the next word I can make nothing; the last three characters, as I have said, 
are certain, and the first seems certainly ?. At all events that is the reading of all my throe copies. as well as of Mr. Pilter's copy.

For the construction of פר, 200 Numb. xxiii, 3 ; Judg. ix, 48.

Dr. Neubuuer is cloarly right in suggesting $7 \mathrm{TP}$, written defectively for

The verb which follows is certified by its recurrence in the next line. In the latter line, the second letter hrs to be supplied, which I suppose to be the $\Omega$ of Hithpael, though Dr. Neubauer suggests (with less probability,

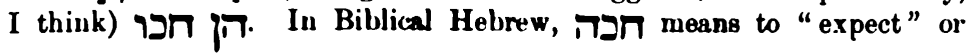
"desire engerly ;" here the Hithpuel would have the sense of "working eagerly at" a thing.

If my reading is right, בירד would be the castle at the northeastern corner of the Temple aren, newr the Virgin's Pool, which is mentioned in Neh. ii, 8; vii, 2, and is called Bripos by Josephus ("Antiq.," 15, 11, 4), the Antonia of the Romass. In this case, the word would not be a late one, aw is usually assumed. The omission of the article may be explained by the use of the word as a proper name. In 1 Chron. xxix, 1, 19, Birah is used for the whole Temple. Mr. Pilter's copy has בימר insterul of but this is untranslateable.

Line 4. The fint worl of this line is difficult both to read and to construe. My copies have בקב . ה), which is also the reading of Mr. Schick's facsimile; but I cannot translate it. Mr. Pilter, however, reals . he seems to resul only one he, and this reading, with much hesitation, I have ventured to sulopt.

It is, however, very probable that Dr. Neubauer is right in making ב ב־ and then reading and of the preposition with the translation : "And they worked eagerly in the . . . . at a hole."

For the phrnse iv רes compare Gen. xv, 10. We may notice that לקר for foritten defectively.

The vaw ronversive of 1 בๆף unmistakeably marks the Hebrew character of the inscription. It may he added that M. Stanislas Guyard has lately pointed out the existence of a "true" wavo conversive in Assyrian (" Recueil de Travaux relatifs à la Philologie et à l'Archéologie egyptiennes et assyriennes," ii, 4, p. 135, note 5).

The scriptio plena of Nyms is remarkable. In Biblical Hebrew we find only the Kal formatives Nצy, מוצ' not the Hiphil

ברכר is the common Biblical term for the "pools" or "reservoirs" which existed at Jerusalem and elsewhere. We may observe that the Pool of Siloum is called "the B'rechah" par excellence, as though it were the chief reservoir at the time the inscription was made.

I explain as a compound of the preposition $ב$ and the noun יתND, a scriptio plena of the Biblical מתז. In the Bible the 
word is used only of time, but it properly means "extension," and the. temporal use of it is derived from the local one.

Throughout the inscription ip is written in its uncontracted form. This cannot be regarded as an Aramaism, but, on the contrary, as a mark of antiquity, like the use of ית in a local sense.

Line 6. The first word of line 6 is certainly 7 TNת. The sense seems to require some word parallel in meaning to Nisר. I can think only of תחת, 'aleph being written as in ימא, and hé taking the place of tau, as in the TISN of the second line. But I must confess that the meaning of "lower part" would be more suitable to the Siloam end of the tunnel than to the other, to which it refers. It may, however, signify the grooved channel in the floor of the conduit, through which the water flows.

The next word is read הנקובה by Dr. Neubauer, doubtless correctly.

The noun in Biblical Hebrew, מתז taking its place. The participle used of the quarrymen who cut the stone for Solomon's temple in 1 Kings v, 15 (Heb. v. 29).

Ti is used adverbially, as in Dan. x, 17. I could see no point between it and $25 \pi$, and therefore conclude that it was regarded as an enclitic.

Additional Note.--Since the above was written, Dr. Neubauer has made two happy suggesticns, which not only explain the difficult passage in line 3, but are also of great topographical importance. He proposes to make the first letter of בירד the preposition as in בצר, and to regard ירד as a geographical name Yerah. The translation will accordingly be: "They worked eagerly at the excavation in Yerah." Now Yerah at once reminds us of the famous passage in Gen. xxii, 14, where Dr. Neubauer's suggestion justifies us in the rendering, " of which it is said to-day, in the mount of the LoRD Yerah." Here the name is identified with the Templemount, that is, with the very part of Jerusalem in which the tunnel was excavated. But more than this, Yerah is the same word as Yeru, and Yeru forms the first part of Jerusalem. Since Melchizedek is called King of Salem, it is possible that the western portion of Jerusalem was originally known as Salem, the Temple-mount being Yerah or Yeru, the enclosure of the two sites within oue wall giving rise to the compound name Jerusalem. It is noticeable that the punctuators make the latter word a dual. Dr. Neubauer's other suggestion is equally attractive. He would read מצד ירודה and render "to Motsah of Yeru-ziddah." Motsah was a place belonging to Benjamin, and near Jerusalem, according to Josh. xviii, 26, and my copy shows that the character I have read as daleth is not formed like the other daleths of the inscription, but like the left hand part of the tsadhé. With Yeru-ziddah, I would venture to compare the still unexplained name of Bezetha, on the north-east side of Jerusalem. Bezetha might very well represent Beth-Zidtha. 
Dr. Neubauer has also drawn my attention to Is. viii, 6 : "Forasmuch as this people refuseth the waters of Shilouh that go softly," where we should rather render "despiseth." The passage looks as if Ahaz had made a conduit for the rapid passage of the waters of Siloah, while the people irouically said of them that they went only softly. In this case the tunnel in which the inscription has been found would have been either constructed or repaired by Ahaz.

After the above had been revised, I read the article of Dr. Kautzsch on the Inscription in the last number of the Zeitschrift des deutschen Palaestina-Vereins (iv. 1, 2), but learned nothing from it. A "copy" of the Inscription is published, which is as incorrect as that published in the last Quarterly Statement of the "Palestine Exploration Fund," and Dr. Kautzsch's readings basod upon it are naturally worthless, as is also, for the same reason, his supposition that the Inseription is not older than the age of Hezokiah.

\section{II}

\section{POSTSCRIPT.}

A FEW words may be added by way of supplement and correction to the above. In the first place, an important argument on behulf of its antiquity may be drawn from the fact that the modern Pool of Siloam is called in it simply "the Pool." This implies that no other artificial reservoir of the kind existed at the tine in Jerusaleru. We are thus referred to an earlier epoch than the age of Isaiah, who mentions no less than four reservoirs, "the upper poul" (Is. vii, 3), "the lower pool" (Is. xxii, 9), " the old pool " (Is. xxii, 11), and the newly made " ditch," or more properly "tank" (ib.). The latter, I funcy, was the reservoir still existing to the south of the Pool of Siloam, which I am inclined to identify with " the old porsl." The Pool of Siloam is called "tho pool of Siloah by the king's garden," in Neh. iii, 15, and "the king's pool," in Neh. ii, 14, a designation which seens to show that it had been constructed by some famuus covereign. We know of none before the time of Ahaz and Hezekiah who could have executed the work, except either David or Solomon. As no other artificial reservoir appears to have existed in Jerusalem when the inscription was engraved, it is more probable that the reservoir was mude shortly after the conquest of Jebusi by David, and the encirclement of the new capital hy a single wall, than when the Temple was actually being built.

It is difficult to suppose that the reservoir existed before the conduit which supplied it with water from "the dragun well," as it is termed in Neh. ii. 13. I believe, therefore, that the reference in 18. viii, 6-" "forasmuch as this people refuseth the waters of Shiloah that go softly,"-must be to the reparation of the tunnel by Ahaz, not to its original excavation. Ahaz had cleared out the pasenge, and so allowed the - water to flow rapidly 
through it ; his disaffected subjects ironically declared that it went only slowly.

The two culs de sac found in the conduit, occur, according to Colonel Warren's measurements, at a distance of 900 feet from its outlet into the Pool of Siluam. The two false cuttings "go in for about 2 feet each" on either side of the tunnel. Here, therefore, must have been the place in the middle of the conduit where the two bodies of workmen met, to find that they had not followed exactly the same line, but that the ends of their two tunnels overlapped each other. A pussage was accordingly cut from the one to the other, the space between the two turning out to be not more than the average breadth of the conduit itself.

Since the publication of my pamphlet, I have received a letter from Mr. Pilter, in answer to my questions about certain doubtful characters in the inscriptions. Another visit to the inscription for the purpose of specially studying the doubtful letters J had indicated, has had the following result. In the first line the reading דבר is settled, the first character of the work being ummistakably a daleth, not an 'ayin. We must therefore translate "This is the history of the excavation." It is further clear that the inscription was originally intended to commence with the words "Behold the excavation," and that the smooth upper part of the tablet was intentionally left uninscribed:

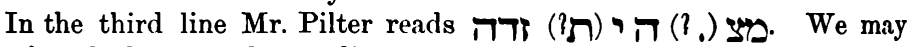
therefore look upon the reading Motsah Yeru-siddah as fairly certain, siuce my copies leave no doubt that the point follows the $\rightarrow$, and does not precede it, while the doubtful letter can well be a resh. At the end of the line Mr. Pilter still reads ביפדה. I believe, however, that I distinctly saw בירת.

At the beginning of line 4, Mr. Pilter finds נקבד . חכר, the first word being "clear." This is very satisfactory, and does away with the necessity of assuming the difficult hithwael form. Mr. Pilter adds that some of the letters are no longer so clear and distinct as they were; "perhaps Dr. Guthe's repeated washings of the stones to get rid of our candle-grease, and make his own gypsum cast, have washed away some of the lime deposited, which was so useful to us."

A. H. SAYCE. 


\section{The Date of thg Siloak Ingcription.}

Proressor SAYCe has, I believe, overlnoked certain considerations which bear on the date to be assigued to the Siloam inscription.

On p. 145, he gives it as his opinion that it represents an earlier stage of the Semitic alphabet than the Moabite Stone, and he assigns it with some confidence to the time of Solomon. On p. 152, however, with his usual candour, he draws attentiou to an historical argument of great weight, brought forward by Dr. Neubauer, which would bring the date down to the reigu of Ahaz. But the palseographical evidence, he argues, is "wholly" in favour of the earlier date.

On the other hand, I think that it may be maintained that the palrographical probabilites, as well as the historical evidence, are in favour of the later date.

The Moabite stone belougs to the beginning of the 9th century B.c. If the Siloam inscription is of the time of Solomon, it would belong to the beginning of the loth century, if to the time of Ahaz to the middle of the 8th. Here then is a very definite issue. To the practised eye of the palæographer, there ought to be no great difficulty in deciding whether the inscription is either a century older, or more than a century later than the reign of Mesha.

The sole argument urged by Professor Sayce in favour of the earlier date is that three of the Silonn letters, tsadhe, wave, and zayin, seem to him of more archaic forms than on the Moabite Stone. At the same time he admits that several other letters belong to the more recent type which is used in the legends on the ancient Hebrew seals.

Now even if we almit the ansumption as to the antiquity of the forms of the three letters, the conclusion by no means follows. It may be laid down as a palrographic canon, that the date of an inscription is to be determined by reference $t$ ) the most recent rather than to the most archaic forms which it contrins. The presence of one or two late forms is decisive evidence of the late date of a whole inscription, while the presence of one or two early forms is of no very grent significance, as they can be accounted for as local survivals. For example, in Athenian inscriptions of the 5th century, we find the archnic form of the lambda, $\checkmark$, whereas the new form $\Lambda$ has already made its appearance in the Greek alphabet in the 7th century, as is evidenced by the Abu Simbel inscription. The old form of the lambda at Athens is clearly a mere survival, and it would be preposterous on such a ground to argie that an inscription such as the Erechtheum survey must be antedated by three centuries, and assigued to a time earlier than the reign of Psummetichus. But this is in fact what Professor Sayce has done, when he ante-dates his inscription on the sole evidence of two or three letters which seem to exhibit exceptionally early forms.

It must be contended that such $\mathfrak{a}$ mode of argument is illegitimate, and 
that the Siloam inscription, like all other inscriptions, must have its date determined by reference to the age of the most recent of the forms which it exhibits.

Now at least half of the Siloam letters appear in forms which are unmistakably later than those on the Moabite Stone. The curvature to the left of the tails of the tailed letters, viz., beth, kaph, mim, nun, and pe is more pronounced than on the Moabite Stone. Here we see in operation one of the chief causes which ultimately transformed the old Semitic alphabet. The cheth with three bars is also later than the Moabite form with two bars, and so is q'oph, whose head is partly opened, while the earlier form is completely closed.

But an argument to which still greater weight must be assigned is derived from the variant forms in which the letters aleph, waw, mim, and resh are written. The old Moabite forms of these four letters are used in the Siloam inscription side by side with the later forms, which subsequently supplanted them. These letter's establish decisively the fact that the Siloam alphabet is a TRANSITION ALPHABET, belonging to a period intermediate between the Moabite alphabet of the 9 th century, and the newer forms by which in the 6th century they were replaced.

Referring to the Siloam alphabet given by Professor Sayce on p. 144, the first aleph is the form on the Moabite Stone, while the second is the 6th century form which is found in the Gebal and the Nora inscriptions, and also on the early Hebrew shekels, which are ascribed by de Saulcy and Lenormant to the times of Ezra and Nehemiah. Again, the first form of resh approximates to the Moabite form, while the second is later. The same is the case with roaw. The second form in Professor Sayce's table is Moabite, while the first, instead of being earlier, as Professor Sayce alleges, is decisively later, as is proved by its being used on the early shekels of the time of Ezra.

The two forms of mim, however, yield an argument so conclusive that they would by themselves suffice to settle the controversy. We actually have in the Siloam inscription, side by side, the two forms of this letter which are commonly used as the most convenient test to distinguish between the first and second epochs of the Semitic alphabet. The earlier, or zigzag form, is essentially the same as the Moabite form, and occurs twelve times. In the form which it had during the second epoch, with the horizontal bar and the cross stroke, the letter occurs twice, in lines 3 and 5. Now this later form is not found on the Moabite Stone, or in the earlier Phœnician inscriptions, or on the Assyrian Lion weights which belong to the beginning of the 8th centary. On the other hand, it is found on the Eshmunazar sarcophagus, in the Gebal inscription, in the second Sidonian, and many other inscriptions from the 6 th century downwards. On the Assyrian contract tablets, however, which belong to the 7th century, it is usually found, but occasionally approximates to the earlier form. Now in the Siloam inscription, the Moabite, or 9th century form appears twelve times, and the Sidonian or 6th century form appears twice. In the 7 th century, as we learn from 
the contract tablets, the old form had nearly disappeared; while at the time when the Siloam inscription was engraved, tbe new form was just beginning to come in. The evidence furnished by this letter alone might enable us with considerable confidence to assign the Siloan inscription to the middle of the 8th century, the exact date of the reign of Ahaz.

Professor Sayce bases his sole argument for the early date on the ussumption that the forms of the three letters, waw, zayin and tsadhe are older than those on the Morbite Stone. Even if this were the case, his conclusion would by no means follow, the later forms of mim and other letters affording decisive proof that the more archaic forms must be regarded only as survivals.

But I cinnot even admit that the forms of these three letters have the antiquity that is claimed for them. Much, no doubt, may be said in favour of the archaism of the forms of tsadhe and zayin, but with regard to waw, the very form which Profesor Sayce considers to be so ancient is actually the later Hebrew form, exactly as found on the shekels of the tine of Ezra, and manifestly the trunsition form from which the Asmonean letter was obtained. Both zayin and toudhe are letters of comparatively rare occurrence, and the evidence as to their history is therefore scanty. The letter zayin does not happen to be met with on any of the early shekels, but' the looped form, which Professor Sayce considers to be so early, is found on the coinage of Bar Cochba, which was imitated from the earlier shekels, and hus actually been transmittod to the modern Samaritan alphabet.

As to the very peculiur shape of tacedhe, it seems imponsible that it can have been the parent of the Moabite form, but on the other hand it can be connected without nuch difticulty with the form on one of the early shekels. On the whole, it may be affirmed that the weight of the evidence tends to show that Professor Snyce's three archaic lettens are nerely local Hebrew forms, and decidedly posterior to the Moubite letters.

The couclusion, therefore, is that out of the twenty letters in the Siloam inscription eleveu or twelve exhibit forms later than the Moabite Stone, that not one is decisively enrlier, nnd that even if this were the case, it would not affect the argument. Indeed, if it were not for the early forms of he and lamed, it would not be inpossible to bring the inscription down almost to the time of the Captivity. The palæographic probabilities tend; however, very strongly to support the ingenious conjecture of Dr. Neubauer that the conduit was excavated in the reign of Ahaz, that is about the middle of the 8th century.

It may be noted in conclusion that the Siloam inscription throws valuable light on the date and affiliation of the South Semitic alphabet's. The peculiar double-louped form of tsadhe connects itself with the doublelooped forms of this letler, which olraracterize the South Semitic alphabets, e.g., the Hinyaritic $B$, the Harra $\Theta$, and the Thugga 8. So again the looped zayin is connected with the Himyaritic form of the letter ' which is also looped.

IsAAC TAYLOR. 